\title{
PENDAMPINGAN MENULIS CERITA RAKYAT UNTUK MENINGKATKAN APRESIASI SASTRA DI SMP NEGERI 18 SUNGAI RAYA
}

\author{
Lizawati $^{1}$, Elva Sulastriana ${ }^{2}$, Eti Ramaniyar ${ }^{3}$ \\ ${ }^{1,2,3}$ Program Studi Pendidikan Bahasa dan Sastra Indonesia, Fakultas Pendidikan Bahasa dan Seni, \\ IKIP PGRI Pontianak, Jalan Ampera Nomor 88 Pontianak \\ ${ }^{1}$ e-mail: Eramaniyar25@gmail.com
}

\begin{abstract}
Abstrak
Tujuan kegiatan pengabdian adalah memberikan pelatihan menulis cerita rakyat untuk meningkatkan apresiasi sastra di SMP N 18 Sungai Raya. Sasaran kegiatan adalah siswa kelas VIII SMP N 18 Sungai Raya berjumlah 24 siswa. Pelaksanaan pengabdian di dalam kelas VIII SMP N 18 Sungai Raya.. Metode pengabdian yang digunakan adalah ceramah, diskusi, Tanya jawab, pendampingan dan penugasan. Kegiatan pengabdian mulai dari tahap persiapan yakni observasi dan sosialisai, sedangkan untuk pelaksanaan mulai dari penyajian materi, praktik, refleksi, dan evaluasi. Hasil kegiatan pengabdian adalah: (1) Pelaksanaan kegiatan pengabdian terselenggara dengan baik dan lancar sepanjang kegiatan berlangsung; (2) pelaksanaan pengabdian telah berhasil dilaksanakan, keberhasilan pelaksanaan pengabdian ditunjukkan dengan meningkatnya pengetahuan dan keterampilan menulis cerita rakyat; dan (3) Siswa dapat menulis cerita rakyat dan mengambil pesan yang tersirat maupun tersurat.
\end{abstract}

Kata kunci: pendampingan, menulis, cerita rakyat

\begin{abstract}
The purpose of community service activities is to provide training in writing folklore to increase literary appreciation at Sungai N 18 Middle School. The target activity is students of class VIII of SMP N 18 Sungai Raya with 24 students. Implementation of service in class VIII SMP N 18 Sungai Raya. The service methods used are lectures, discussions, questions and answers, assistance and assignments. Service activities start from the preparation stage, namely observation and socialization, while for the implementation starts from the presentation of material, practice, reflection, and evaluation. The results of the community service activities are: (1) The community service activities are carried out properly and smoothly throughout the activity; (2) the implementation of community service has been successfully carried out, the success of community service implementation is shown by the increase in knowledge and skills in writing folklore; and (3) Students can write folklore and take implied or explicit messages.
\end{abstract}

Keywords: assistance, writing, folklore

\section{PENDAHULUAN}

Apresiasi cerita rakyat dilakukan sebagai wadah ke tahapan apresiasi sastra lainnya. Kegiatan apresiasi ini tentunya harus berjalan dengan diiringi oleh berbagai pihak yang terlibat dalam pelaku pendidikan termasuk lingkungan sekolah, keluarga, masyarakat sekitar. Dukungan dari berbagai pihak sangat 
diharapkan siswa untuk meningkatkan apresiasi sastranya. Masyarakat pemilik cerita rakyat hendaknya menuturkan kembali cerita rakyat yang dimiliki oleh leluhurnya. Guru pada saat menutup pelajaran hendaknya menyinggung cerita rakyat yang menjadi petuah untuk meningkatkan apresiasi sastra siswanya. Tujuannya untuk memberikan dukungan terhadap apresiasi sastra siswa. Dengan demikian siswa menjadi mahir dalam mengenal, memahami dan menghayati cerita rakyat daerahnya masing-masing. Pembelajaran sastra adalah sebuah sistem keberhasilannya ditentukan oleh banyak faktor seperti kurikulum, guru, buku sumber pembelajaran serta sarana dan prasarana terlibat di dalamnya. Pembelajaran sastra mengandung maksud agar siswa menghargai kesusatraan bangsa sendiri dan sastra daerah khususnya serta dapat mengenal dan menghayati nilai-nilai yang terkandung dalam karya sastra itu sendiri. Rohman (2012: 16) menyatakan bahwa tujuan pengajaran sastra adalah untuk membangun pengetahuan tentang sastra. Dinyatakan persoalan pengetahuan sastra sebagai tujuan akhir pengajaran sastra secara kongruen adalah persoalan-persoalan konsepsi, hipotesis, dan aspek-aspek yang terkait dengan sastra. Dalam karya ini para siswa diharapkan dapat menemukan nilai-nilai luhur bangsa dan daerah sehingga dapat meningkatkan rasa cinta tanah air dan bangsanya.

Cerita rakyat adalah cerita rakyat yang hidup dan berkembang di tengahtengah masyarakat, dari mulut kemulut dan pada dasarnya disampaikan oleh seseorang pada orang lain melalui penuturan lisan maupun tulisan (Gusal, 2015). Cerita rakyat merupakan sastra lisan yang mencerminkan keadaan masyarakat terdahulu yang mengungkapkan berbagai fenomena kehidupan sosial yang berkaitan dengan sejarah, pengalaman, pandangan hidup, adat istiadat, kepercayaan, politik, cita-cita, dan berbagai kegiatan lain yang terdapat di daerah tersebut. Hal ini berarti di dalam cerita rakyat sebenarnya tersirat kenyataan peran sastrawan cukup strategis, yaitu penyambung lidah masyarakat untuk menyampaikan ide dan realita kehidupan dalam masyarakat di daerah atau di lingkungannya.

Cerita rakyat adalah suatu golongan cerita yang hidup dan berkembang secara turun-temurun dari satu generasi ke generasi selanjutnya yang dikatakan 
sebagai cerita rakyat karena cerita itu hidup dan berkembang di kalangan masyarakat dan semua lapisan masyarakat mengenal ceritanya (Setiawan 2013:8). Unsur-unsur itu membangun kesatuan yang saling menopang sehingga dapat menyatu dan membentuk suatu kesatuan. Bagian-bagian itu bersifat fungsional, artinya pengarang memiliki maksud tertentu secara keseluruhan dalam menciptakan suatu karya sastra, sehingga maknanya dapat ditentukan oleh cerita tersebut secara keseluruhan. Waluyo (2011: 6) menyebutkan unsur-unsur pembangun cerita ksi tersebut yaitu: (1) tema cerita, (2) plot atau kerangka cerita, (3) penokohan dan perwatakan, (4) setting atau tempat kejadian cerita atau disebut juga latar, (5) sudut pandang pengarang atau point of ew, (6) latar belakang atau back-ground, (7) dialog atau percakapan, (8) gaya bahasa/gaya bercerita, (9) waktu cerita dan waktu pencitraan, dan (10) amanat. Menghayati karya sastra merupakan bagian dari tahapan apresiasi. Apresiasi inilah yang mendorong siswa untuk mengenal, memahami, dan menikmati karya sastra. Kemampuan mengapresiasi karya sastra akan muncul pada diri siswa apabila ia sudah mengenal karya sastra.

Perkembangan cerita rakyat di masyarakat yang cukup meluas tidak memberikan kontribusi positif pada pengajaran sastra di sekolah, khususnya yang berkaitan dengan apresiasinya. Ketidaktahuan inilah dapat memberikan gambaran bahwa apresiasi siswa terhadap karya sastra khususnya cerita rakyat cukup rendah. Kondisi ini sepenuhnya bukan kesalahan siswa semata. Lingkungan sekolah, keluarga, dan masyarakat sekitar seharusnya memberikan peranan yang dapat mendukung pendidikan dan pengajaran sastra. Selain itu, pada umumnya cerita rakyat juga tidak terikat oleh waktu dan tempat, dapat terjadi dimana saja dan kapan saja tanpa perlu harus ada semacam pertanggungjawaban pelataran. Kekurangan kejelasan latar tersebut sudah terlihat sejak cerita dongeng dimulai, yaitu yang sering mempergunakan kata-kata pembuka penunjuk waktu seperti: "pada zaman dahulu kala, pada zaman dahulu," dan lain-lain. Demikian juga mengenai penunjuk latar tempat yang hanya sering disebut "di negeri antahberanta," "di negeri dongeng," disuatu tempat dipinggir hutan," dan lainlain. Ketidak jelasan latar tersebut dapat memberikan kebebasan pembaca (anak) 
untuk mengembangkan daya fantasinya kemampuan dan kapan pun mau dibawa, namun bagi orang dewasa, misalnya ingin mengetahui kebenaran dan kepastian latar untuk memberiakn munculnya cerita dongeng yang bersangkutan, menjadi terhambat. Namun demikian, sebagian cerita rakyat juga menunjuk latar tertentu secara kongkrit baik yang menyangkut waktu maupun tempat.

Berdasarkan paparan singkat di atas, di SMP Negeri 18 Sungai Raya Kabupaten Kubu Raya dipandang perlu diadakan pelatihan pendampingan menulis cerita rakyat. Tujuan dari pendampingan penulisan cerita rakyat ini yaitu (1) untuk meningkatkan pengetahuan dan pemahaman siswa terhadap menulis cerita rakyat; (2) untuk meningkatkan kemauan dalam menulis cerita rakyat ; dan (3) untuk meningkatkan keterampilan menulis cerita rakyat dan mengambil pesan yang tersirat maupun tersurat. Adapun target yang ingin dicapai pengabdi dalam melakukan pendampingan penulisan cerita rakyat ini yaitu ketercapaian siswa dalam menulis cerita rakyat serta siswa-siswa tersebut dapat mengambil pesan yang tersirat maupun tersurat terdapat dalam cerita rakyat tersebut.

\section{METODE}

Kegiatan pengabdian berupa pelatihan menulis cerita rakyat. Pelaksanaan kegiatan pengabdian dilaksanakan di dalam kelas VII SMP N 18 Sungai Raya. Subjek kegiatan pengabdian yaitu siswa kelas VIII SMP N 18 Sungai Raya yang terdiri dari 24 orang. Metode yang digunakan dalam kegiatan pengabdian adalah metode ceramah, diskusi, tanya jawab, pendampingan dan penugasan.

Tempat pelaksanaan kegiatan di SMP Negeri 18 Sungai Raya Kabupaten Kubu Raya yang dilaksanakan pada tanggal 15-22 April 2019. Jadwal kegiatan program Pendampingan Menulis Cerita Rakyat Untuk Meningkatkan Apresiasi Sastra di Smp Negeri 18 Sungai Raya Kabupaten Kubu Raya yang dilakukan oleh tim PkM melalui beberapa kegiatan atau langkah-langkah pelaksanaan kegiatan PkM ini.

Langkah-langkah yang dilakukan dalam pelatihan menulis cerita rakyat untuk meningkatkan apresiasi sastra di SMP Negeri 18 Sungai Raya Kabupaten Kubu Raya adalah sebagai berikut. Persiapan, Tahap persiapan pelaksanaan 
pengabdian pada masyarakat di SMP Negeri 18 Sungai Raya Kabupaten Kubu Raya diawali dengan analisis permasalahan yang terdapat di lapangan. Analisis yang dimaksud yaitu melalui observasi langsung ke masyarakat sekitar lingkungan sekolah, observasi di lingkungan sekolah, melakukan komunikasi langsung dengan guru dan siswa lewat wawancara untuk menentukan relevansi masalah dan solusi yang sesuai di SMP Negeri 18 Sungai Raya Kabupaten Kubu Raya. Pelaksanaan Pelatihan, tahap pelaksanaan program pendampingan menulis cerita rakyat untuk meningkatkan apresiasi sastra di SMP Negeri 18 Sungai Raya Kabupaten Kubu Raya meliputi kegiatan sebagai berikut. Pertama, persiapan pelaksanaan kegiatan dimulai dengan penyelesaian administrasi bagi peserta pelatihan meliputi pendaftaran peserta yang akan mengikuti pelatihan. Kedua, pemberian materi cerita rakyat pada mata pelajaran bahasa Indonesia oleh narasumber kepada peserta, dan yang ketiga, kegiatan simulasi menulis cerita rakyat oleh peserta. Penyajian materi, materi yang disajikan tentang strategi menulis cerita rakyat dilakukan secara langsung dipraktikkan oleh tim pengabdian. Materi yang disajikan membicarakan bagaimana strategi agar siswa dapat menulis cerita rakyat serta memahami unsur-unsur pembangun cerita rakyat tersebut. Penugasan menulis cerita rakyat, para siswa diberikan tugas untuk menulis cerita rakyat. Peran tim dosen adalah mendampingi apabila ada siswa yang mengalami kesulitan dalam menulis cerita tersebut. Refleksi dan Evaluasi, tahap refleksi pada pengabdian ini diakhiri dengan melakukan perbaikan terhadap kekurangan maupun kesulitan yang dialami siswa pada saat mengerjakan atau membuat cerita rakyat, sedangkan tahap evaluasi dimaksud untuk melihat ketercapaian target luaran pengabdian, proses pelaksanaan dan hambatanhambatan yang terjadi dalam pelaksanaan kegiatan serta solusi yang dilakukan. Diharapkan dengan adanya tahap refleksi dan evaluasi program pengabdian pada masyarakat yang dilakukan setelah pelaksanaan kegiatan dapat memberikan manfaat bagi tim pelaksana, sekolah khususnya siswa agar menjadi generasi literat dalam mengapresiasi karya sastra. 


\section{HASIL DAN PEMBAHASAN}

Tim pelaksanaana dari kegiatan ini adalah para tenaga pengajar (dosen) Program Studi Pendidikan Bahasa dan Sastra Indonesia IKIP PGRI Pontianak yang berjumlah 3 (tiga) dengan melibatkan mahasiswa dalam pelaksanaan pengabdian.

Tahap pelaksanaan pendampingan menulis cerita rakyat di SMP N 18 Sungai Raya Kabupaten Kubu Raya meliputi kegiatan sebagai berikut. Pelaksanaan kegiatan dimulai pada hari Rabu, tanggal 23 Oktober 2019. Tahap pertama yang dilaksanakan yaitu dengan penyelesaian administrasi/ registrasi bagi peserta pelatihan yang dilaksanakan selama 15 menit dimulai pada pukul 08.30 WIB dengan jumlah peserta yang telah melakukan registrasi sebanyak 24 peserta. Setelah registrasi selesai dilaksanakan kegiatan berikutnya yaitu pembukaan yang disampaikan oleh wakil kepala sekolah SMP N 18 Sungai Raya Kabupaten Kubu Raya dan sambutan ketua tim PKM yang memberikan pengantar dan dilanjutkan dengan pendampingan menulis cerita rakyat. Kegiatan ini dilaksanakan sampai pukul 11.30 WIB.

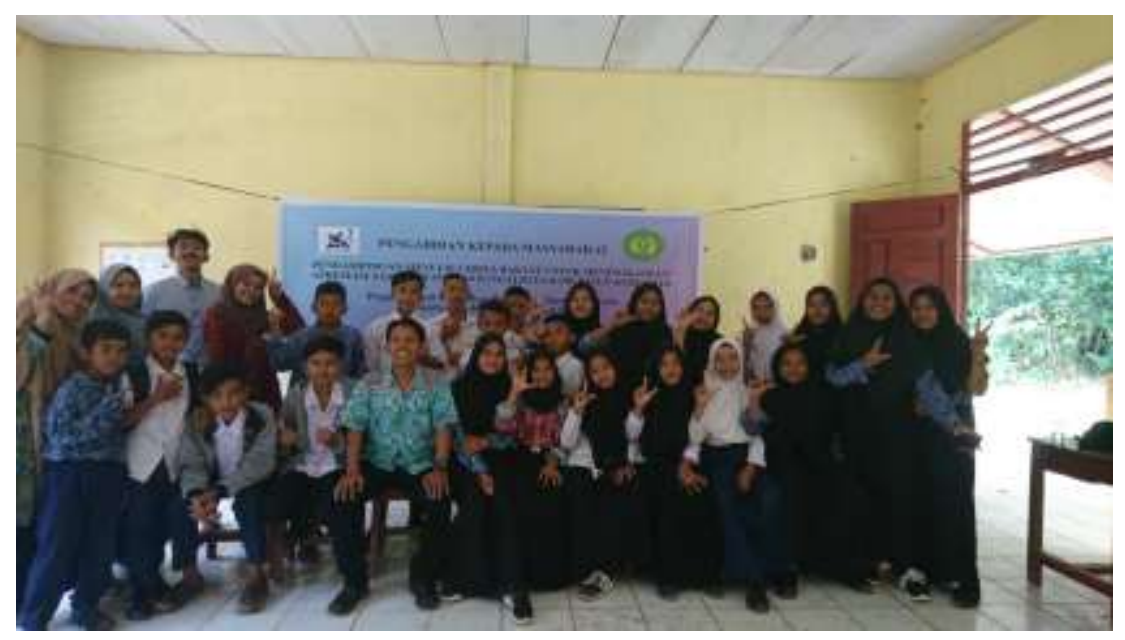

\section{Gambar 1. Tim PkM dan Guru serta siswa SMP N 18}

Sebelum membahas cerita rakyat, terlebih dahulu menanyakan kepada siswa "apakah menyukai atau mengenal cerita rakyat" dari beberapa jawaban siswa ada yang menjawab menyukai dan mengenal cerita rakyat ada juga beberapa siswa yang menjawab tidak menyukai suka. Jawaban itu mereka utarakan dengan alasan 
tidak tahu cerita rakyat ayang ada di kalimantan Barat, jadi lebih mengenal cerita rakyat yang di luar Kalbar lewat televisi atau buku cerita rakyat. Kegiatan simulasi cerita rakyat dimulai dengan penayangan cerita rakyat melalui proyektor dan materi yang telah disiapkan. Hal ini terlihat dari seluruh siswa yang benar-benar ikut menyimak apa yang telah disampaikan oleh ketua tim PKM. Pada saat pelaksanaan siswa disuruh untuk menyimak tayangan dan materi yang diberikan yang telah disediakan tim PKM para siswa juga antusias untuk menyimak. Setelah itu, siswa membentuk kelompok untuk menulis cerita rakyat yang mereka ketahui dan didampingi oleh tim PKM.

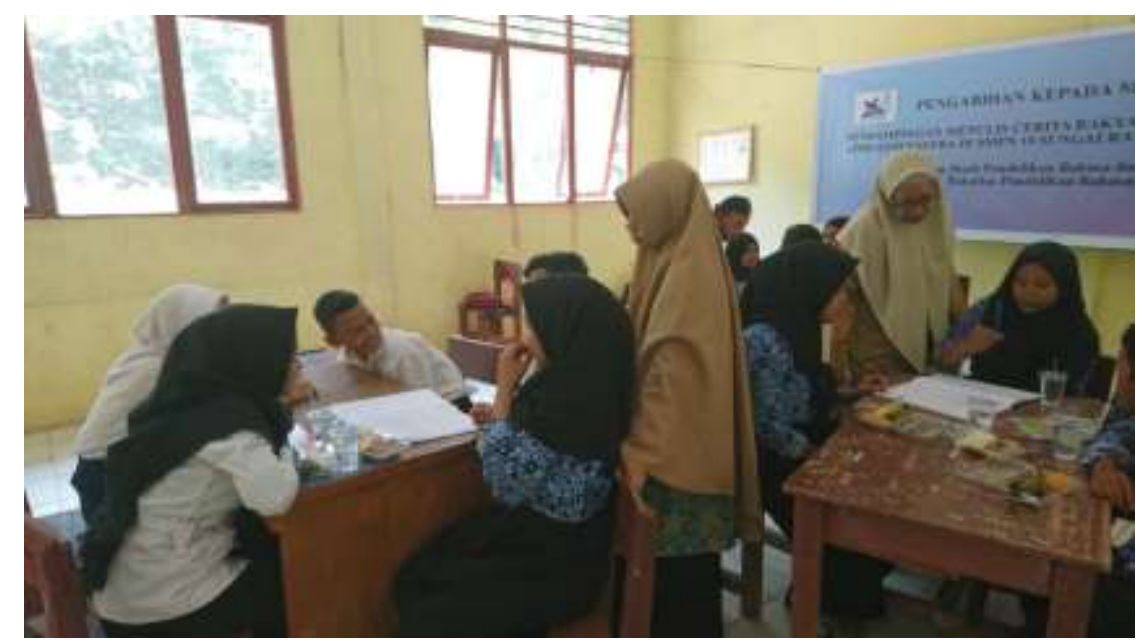

Gambar 2. Tim PKM Mendampingi Siswa Pada Saat Menulis Cerita Rakyat

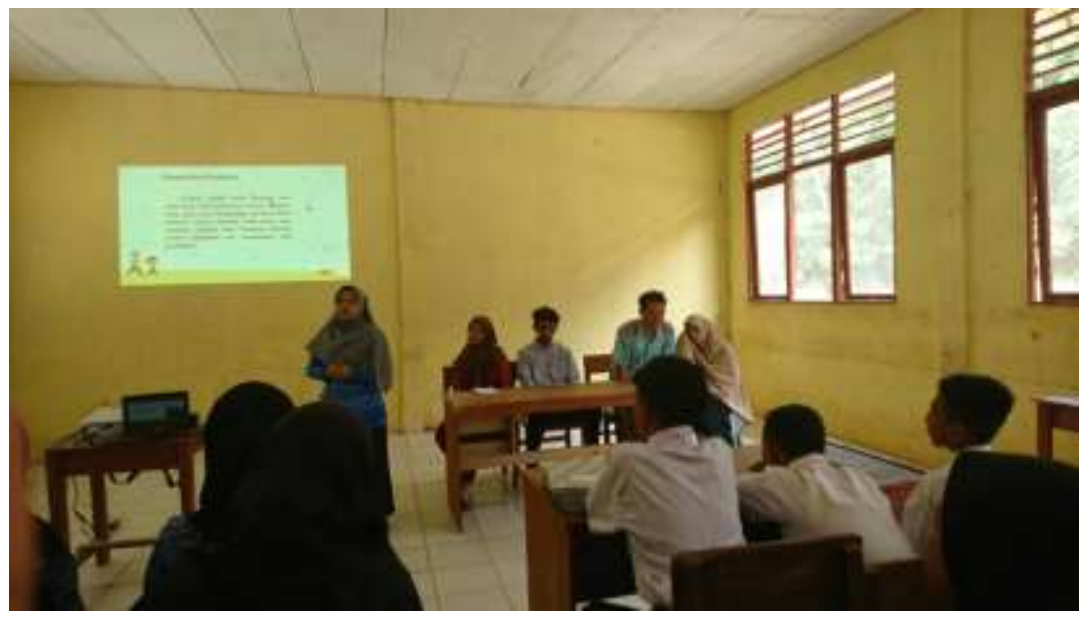

Gambar 3. Penyampaian Materi Oleh Tim PkM 
Tim penyaji kemudian menyampaikan materi tentang menulis cerita rakyat beserta unsur-unsur pembangun dalam cerita rakyat. Dengan dilaksanakannya pelatihan, siswa sudah mulai memahami bagaimana cara menulis cerita rakyat. Sehingga diharapkan pada saat menulis cerita rakyat, siswa juga dapat memahami maksud tersurat maupun tersirat dalam cerita rakyat tersebut.

Tahap akhir dari kegiatan pengabdian tersebut adalah tim dosen melakukan evaluasi guna memperbaiki kelemahan yang terjadi selama pelatihan berlangsung dan dijadikan bahan pertimbangan untuk melakukan kegiatan pengabdian selanjutnya. Tahap evaluasi dimaksud untuk melihat ketercapaian target luaran pengabdian, proses pelaksanaan dan hambatan-hambatan yang terjadi dalam pelaksanaan kegiatan serta solusi yang dilakukan. Diharapkan dengan adanya evaluasi program pengabdian pada masyarakat yang akan dilakukan setelah pelaksanaan kegiatan dapat memberikan manfaat bagi tim pelaksana, sekolah khususnya siswa yang didampingi dalam menulis cerita rakyat lebih mengapresiasi sastra.

Evaluasi pada tahap pelaksanaan berjalan dengan lancar. Dari jumlah peserta yang ditargetkan sebanyak 24 orang siswa tidak ada siswa yang tidak hadir. Evaluasi pada tahap pelaksanaan pendampingan menulis cerita rakyat dan sesi tanya jawab tidak mengalami kendala yang berarti, hanya saja waktu yang disediakan untuk pendampingan dirasa terlalu singkat untuk lebih maksimal. Sehingga pemateri hanya menyampaikan poin-poin penting dalam pendampingan menulis cerita rakyat untuk meningkatkan apresisi sastra.

Evaluasi pada tahap pendampingan menulis cerita rakyat ini, semua peserta sangat antusias selama mengikuti kegiatan. Antusias siswa terlihat dari kehadiran siswa semua dikelas tersebut pada saat mengikuti pelatihan menulis cerita rakyat. Kendala yang dihadapi adalah kendala waktu yang terlalu singkat untuk melakukan lebih waktu dalam menulis. Sehingga pemateri hanya menyampaikan poin-poin penting dalam menulis cerita rakyat. Pada saat materi disampaikan oleh dosen pengabdi, banyak siswa yang mengajukan pertanyaan diantaranya mengenai bagaimana menentukan tema dalam cerita rakyat, apakah sama antara judul dan tema. 
Keberhasilan siswa dalam membuat cerita rakyat tergolong baik. Adapun hasil yang diperoleh siswa setelah mengikuti pelatihan menulis cerita rakyat ini yaitu meningkatkan pengetahuan dan pemahaman siswa terhadap menulis cerita rakyat, meningkatkan kemauan dalam menulis cerita rakyat dan meningkatkan keterampilan menulis cerita rakyat dan mengambil pesan yang tersirat maupun tersurat.

\section{SIMPULAN}

Setelah diberikan pendampingan menulis cerita rakyat peserta memiliki atusias yang tinggi terhadap cerita rakyat dan mampu memberikan apresiasi terhadap karya sastra. Hal ini ditunjukkan dengan meningkatkan pengetahuan dan pemahaman siswa terhadap menulis cerita rakyat, meningkatkan kemauan dalam menulis cerita rakyat dan meningkatkan keterampilan menulis cerita rakyat dan mengambil pesan yang tersirat maupun tersurat.

Siswa yang belajar bahasa Indonesia khususnya materi cerita rakyat seharusnya disuguhkan cerita rakyat Kalimantan Barat agar mereka lebih mengenal cerita rakyat lokal yang merupakan kekayaan harus dilestarikan sehingga dapat diwariskan ke generasi bangsa. Selain itu, apresiasiasi terhadap karya sastra akan tumbuh jika sekolah menggalaknya pentingnya membangun generasi literat.

\section{UCAPAN TERIMA KASIH}

Terima kasih diucapkan kepada pihak mitra pengabdian kepada masyarakat yakni siswa-siswa SMP N 18 Sungai Raya serta dewan guru dan Kepala SMP N 18 Sungai Raya atas partisipasinya dan kerja samanya. Serta pihak IKIP PGRI Pontianak yang telah mendukung memberikan bantuan dana untuk kelancaran kegiatan pengabdian kepada masyarakat.

\section{DAFTAR PUSTAKA}

Gusal, L., O. (2015). Nilai-nilai pendidikan dalam cerita rakyat sulawesi tenggara karya la ode sidu. Jurnal humanika. 3(15). 
Rohman, S. (2012). Pengantar metodologi pengajaran sastra. Jogjakarta: ArRuzz Media.

Setiawan, Y., B. dkk. (2013). Bias gender dalam cerita rakyat (analisis naratif pada folklore dengan cerita rakyat indonesia bawang merah bawang putih). Jurnal komunikasi, 5(2).

Waluyo, H., J. (2011). Pengkajian dan apresiasi cerita fiksi. Surakarta: Sebelas Maret University Press. 